\title{
Knowing Celepuk Siau Through Illustration Media To Children
}

\author{
Bambang Candra Purnama, Deni Albar \\ Faculty of Magister Design \\ Universitas Komputer Indonesia \\ Bandung, Indonesia
}

Deni.albar.email.@unikom.ac.id

\begin{abstract}
Celepuk Siau (Otus Siaonesis) is one of the species, and also endemism animal of Siau Island Sulawesi Indonesia, which is now considered Critically Endangered. To instill a sense of belonging and loving of the species on children, are the important thing to build a sense of protecting and hopefully take care of it in the future, Considering animals are one of the important on human balance of living. Based on those problem it is required a medium that can inform Celepuk Siau owl properly. Where it aimed to make society and target audience specifically recognize and loving Celepuk Siau owl more. An Illustration Media is one of the chosen solution, this is based on children fondness of visual interest or drawing and image.
\end{abstract}

Keyword-Endangered Bird, Information, Illustration Media, Children

\section{INTRODUCTION}

Indonesia has $16 \%$ of the 10,000 birds in the world, but in fact almost 1,600 of the species of birds, 126 of them are endangered, unprotected and reduced in population (www.burung.org, 2013)3. In fact, the government itself has made laws, one of which is related to threats to wildlife populations and ecosystems, as stated in Law No.5 of 1990 concerning Conservation of Biological Natural Resources and their Ecosystems. One of the IUCN (Class) critically endangered bird is the Strigiformes owl, the "Otussiaonesis" Siau Plop.

Otussiaonesis has a medium body $\pm 17 \mathrm{~cm}$, belonging to the Strigidae family, has a brown body color and dark brown spots on the upper part, and the lower light brown, and eat form of insects or beetles, the bird first discovered by Schlegel in 1873. Current status is not protected but is at risk extinct (Critically Endangered, IUCN). From the specimens or samples studied on the island of Siau in 1866. It is estimated that the current population is not more than 50 adult individuals.

In general, owls are a type of pure carnivorous (raptor) or meat-eating species, including nocturnal species because they live actively at night, scattered around 222 species around the world, except in Antarctica, 26 of them which are found in Asia and Indonesia, is among the families of Tyto, Otus, and Ninox. [1]

Kusrianto explained that illustration is an art of image that is used to provide an explanation for a specific purpose or purpose visually. Kusmiati added that with this illustration, the message to be conveyed will be more memorable because the reader will be easier to remember images than words[2]. literally the media is interpreted as a medium of communication, through by these two meanings, illustrated media understood as a medium of communication, that convey the content of information through the image as an art.

Education expert Dr. Arief Rachman believes that children are easy to absorb information with pictures, "Give children stimuli based of their age. For example, start with form of interesting images. Also involve children with stimulus reading stories that are carried out in an interesting and consistent manner. Images are very important for them, because the child's initial process of getting to know something is by looking. The form of picture can be object itself or other like symbols such as letters and numbers.

Seeing the urgency of the extinction of the world's birds, the relevance of the illustrated media as a medium of information and children as an easy-to-grow figure with the absorption of pictorial and storytelling information, these three aspects are combined as a solution to communicate to children, with the aim of introducing and understanding the urgency of recognizing Siau in early of their age.

\section{METHOD}

In building this research through the stages of creative strategy, starting with qualitative methods with parties that directly or indirectly intersect with the object of research such as environmental practitioners, and supported by other data sources such as books, web and journals. The next stages followed by descriptive method with illustration approach, this descriptive contains of information that related to Siau plop directly got from the results of interviews and other data sources, the results of this information are then simplified and reprocessed into a narrative form of the story which is then channeled through illustration media. 


\section{RESULT}

From the results of related data observations, it was found that the fact that the number of owls in the wild can be said to be heading towards extinction, the threat that occurs is the process of deforestation that is very fast. in 1995 there was a forest area around the Keppeta lake which was in the Siau region, but in 1998 this forest area had been cut down as quoted. In October 1998 a survey was conducted and found the fact that only $50 \%$ of the remaining forest area was in an altitude of $800 \mathrm{~m}$, and even then it could only be accessed through a village called Lau. Research was carried out that there were only a few forest lands that were above 600 altitudes, describing the condition of the area which was very small and narrow.

Illegal sale of animals without prior notice or counsel that is sold openly and does not accordance with the law is also a problem. "More than 70 owls are traded. This is a real threat of saving animals not just ceremonial. the government must change the mindset of the people of this nation to care for animals in this country, as long as it is not done, then the extinction of animals, especially birds of prey, are just waiting for time "(Lim Wen Sin Head of Nature Conservation, Raptor Club Indonesia (RCI).

Owls play an important role in the balance of the surrounding environment, because owls are a type of raptor, which controls the population of preyed animals such as snakes, rats, or insects. which is not commonly well known by the community [3], see Table I.

TABLE I. CAUSES OF EXTENSION

\begin{tabular}{|l|l|}
\hline \multicolumn{1}{|c|}{ Reasearch data } & \multicolumn{1}{|c|}{ Cause of extension } \\
\hline $\begin{array}{l}\text { J Riley dan J.C wardill } \\
\text { in litt 1999. }\end{array}$ & $\begin{array}{l}\text { The ongoing pattern of forest } \\
\text { deforestation in a lack of forest land and } \\
\text { habitat for Siau plop, which only leaves } \\
50 \% \text { of the forest land around the Lake } \\
\text { Kepetta. }\end{array}$ \\
\hline $\begin{array}{l}\text { dr. h. Evy practitioner } \\
\text { of wildlife foundation } \\
\text { in Bandung }\end{array}$ & $\begin{array}{l}\text { The existence of deforestation and lack of } \\
\text { information literature related to owls and } \\
\text { wildlife in general, both visual and } \\
\text { written media that are available and can } \\
\text { be understood by the public. }\end{array}$ \\
\hline $\begin{array}{l}\text { Lim Wen Sin Chief of } \\
\text { Nature Conservation, } \\
\text { Raptor Club Indonesia } \\
\text { RCI) }\end{array}$ & $\begin{array}{l}\text { The practice of illegal buying and selling } \\
\text { of wildlife that is still ongoing today } \\
\text { without thinking about the impact, and } \\
\text { the lack of roles and actions taken by the } \\
\text { government }\end{array}$ \\
\hline
\end{tabular}

Combined by results through descriptive qualitative methods with illustration approach, produce a response to the form of illustrative media, this solution is divided into two categories of illustrative media, the first is the main media, centered on the information content that is directly related to the object of the research, contains of morphology owls in general, Siau plop specifically, activity patterns, their habitats live, cause due to their population decline and facts related to them. then the second media is the form of supporting media, with form of illustration posters, and interactive games that integrate with illustrated story book.

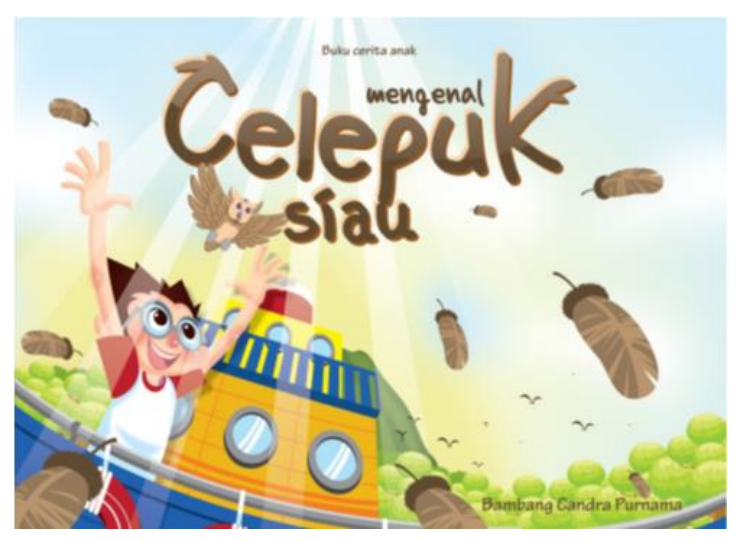

Fig. 1. Illustrated Story Book

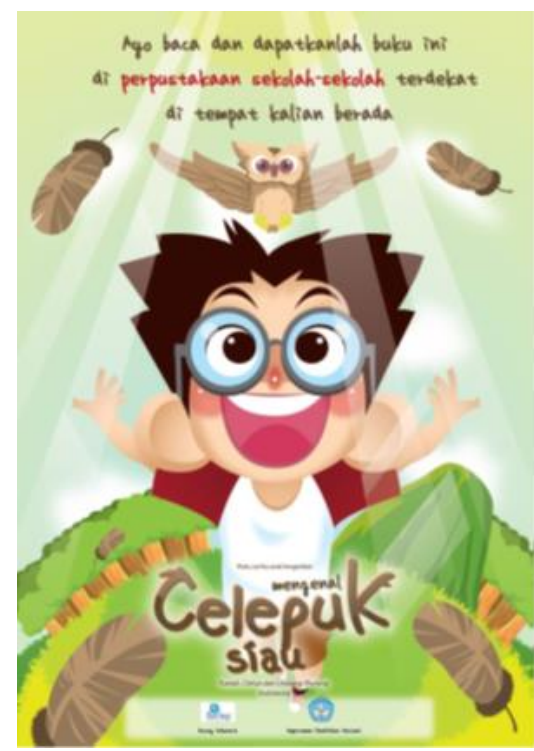

Fig. 2. Poster

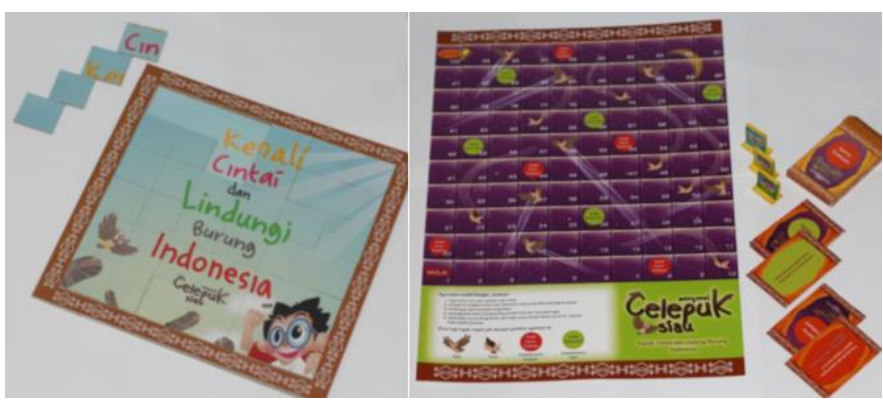

Fig. 3. Boardgame

\section{DISCUSSION}

From various forms of illustration media, the selection of the main media and supporting media is divided into several aspects, the book becomes the main media considered by history of the consistency of the form of books, books work as a documentation tool that is so close to human culture, starting from ancient Egypt, Chinese civilization, to modern times the presence of books always appears in every age, the physicality of printed books is easily to be distributed in geographical conditions in remote areas with minimal electronic information media. Supporting media are strengthening the main media, poster illustrations containing content of persuasive messages and 
suggestions, the boardgame support children to be fun and not easily bored and easier digest the information obtained.

\section{CONCLUSION}

Indonesia is an archipelago country that has many types of animals in the world, many of which are endemic to Indonesia, but in fact many of these animals are threatened towards extinction and even disappear. With illustrated media, children can recognize national identity in other forms such as loving the archipelago of endemic animals, with the hope that when they grow up they can understand how the urgency of extinction of living things, and the problem starts from understanding what Siau Plop is early on.

\section{ACKNOWLEDGMENT}

Alhamdulillah, pray to god Allah SWT for his blessing for make all kind things in my life happens. Thanks to UNIKOM.

\section{REFERENCES}

[1] Romulo, chelsea L. (2012). Geodatabase of Global Owl Species and Owl Biodiversity Analysis, faculty of the Virginia Polytechnic Institute and State University.

[2] Maharsi, Indira (2011) Komik Dunia Kreatif Tanpa Batas, Yogyakarta: Kata Buku.

[3] Drh. Evi . Yayasan Margasatwa Kota Bandung (2012) Mengenal dan mengetahui hewan nokturnal (11 December 2012).

[4] Roots, C. (2006). Nokturnal animal.London:Greenwood press

[5] Papalia, Diane E. Old, Sally Wendkos. Feldman, Ruth Duskin, (2008). Human Development (Psikologi Perkembangan), Jakarta:KENCANA PRENADA MEDIA GROUP.

[6] Supriono, R. (2010) Desain Komunikasi Visual : Teori dan Aplikasi. Yogyakarta: CV Andy Offset (penerbit Andy).

[7] Kusrianto, Adi. (2007) Pengantar Desain Komunikasi Visual Yogyakarta:CV Andy Offset (penerbit Andy).

[8] Zelanski, Paul. Fisher, Mary Pat (2010) Color. China:Pearson Education Inc.

[9] Lebah, Pustaka (2005) My first cartoonal encyclope bee my human body amazing facts and experiments inside book one, Bandung: Pustaka Lebah.

[10] Jion, Eko. (2012) Jenis-jenis Burung Hantu Indonesia (Suku Tytonidae dan strigidae)

[11] Forest watch Indonesia (2009) Perkembangan tutupan Hutan Indonesia

[12] Perhimpunan Pelestarian Burung Liar Indonesia (Burung Indonesia). (2012) Lebih Dekat Dengan Prangko Burung Terancam Punah Indonesia

[13] Wihardandi, Aji. (2013) Celepuk Siau, Misteri Burung Endemik Kepulauan Sitaro

[14] Soekartun, Roikan. (2013) Kartun dan Seni Ilustrasi 